\title{
Seasonal variation of ice ablation at the margin of the Greenland ice sheet and its sensitivity to climate change, Qamanârssûp sermia, West Greenland
}

\author{
Roger J. Braithwaite and Ole B. Olesen \\ Gronlands Geologiske Undersogelse, DK-1350 Copenhagen K, Denmark
}

\begin{abstract}
Monthly ice ablation was measured at the margin of the Greenland ice sheet for June, July and August over 7 years (1980-86). The total winter ablation (September-May) has also been measured, and a simple ablationtemperature model used to assign ablation values to individual months. Under the present climate, the most ablation occurred in June-August (on average $81 \%$ of annual ablation), moderate ablation took place in May and September $(17 \%)$ and very little ablation occurred in October-April $(2 \%)$. The effect of climate change on ice ablation is simulated using the ablation model to recalculate ablation for higher temperatures. Summer ice ablation increases with temperature in the model, but there is proportionally greater increase for May and September, whereas the period from October to April is presently so cold that even a temperature rise of $+5^{\circ} \mathrm{C}$ will hardly increase ablation. The difference in annual ice ablation caused by future climate change will therefore depend upon the seasonal distribution of the temperature change. Changes in precipitation and accumulation will further modify the seasonal variation of ablation.
\end{abstract}

\section{INTRODUCTION}

A warmer climate in the future, due to greenhouse warming for example, would cause increased melting of glaciers and ice sheets, and a resulting rise in world sea level (Warrick and Oerlmans, 1990). Braithwaite and Olesen (1990b) estimated that summer melting at Nordbogletscher and Qamanârssûp sermia (Fig. 1), at the margin of the Greenland ice sheet, will increase by about $0.5 \mathrm{~m}$ water $\mathrm{a}^{-1}$ for each degree rise in summer temperature (i.e. for June-August), but this neglects the possible increase of ablation in other seasons (i.e. for September-May). We now remedy this shortcoming for Qamanârssûp sermia by (1) describing the seasonal variation of ablation at the ice-sheet margin under present climate conditions, (2) estimating the effects of temperature increase, and (3) discussing the implications for monitoring elevation changes of the Greenland ice sheet. A similar study at Nordbogletscher is not possible because there are no reliable winter temperature data at that site.

\section{DATA}

Data from Qamanârssûp sermia, West Greenland (Fig. 1), were used for the present study because ablation measurements at that site were combined with the yearround operation of an automatic climate station. The data, originally collected for planning hydro-electric power generation (Olesen and Braithwaite, 1989) are used to study the impact of the greenhouse effect on the Greenland ice sheet. The relationship between ice ablation and temperature has been described by Braithwaite and Olesen $(1985,1989 a)$. The effect of other climatic elements was examined with an energybalance approach by Braithwaite and Olesen (1990a, c).

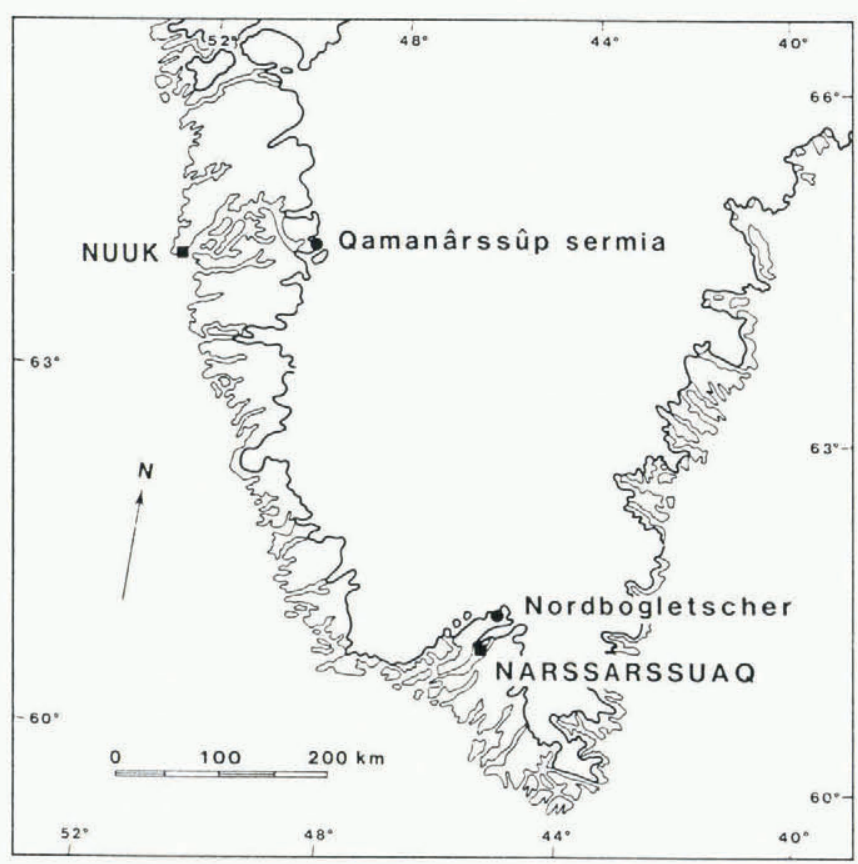

Fig. 1. Location of Qamanârssûp sermia and the nearest permanent weather station at Nuuk, West Greenland. 


\section{Ablation}

Ablation readings were taken from many stakes on Qamanârssûp sermia (Braithwaite and Olesen, 1989b), but the present paper refers only to measurements from stake 751 ( $790 \mathrm{~m}$ a.s.l., $\left.64^{\circ} 28^{\prime} \mathrm{N}\right)$ about $100 \mathrm{~m}$ from the glacier margin (Fig. 2). This is the so-called "daily stake" which was measured almost every day (late afternoon or early evening) from late May to early September for seven summers, 1980-86 (Olesen and Braithwaite, 1989).

The observations involved measuring the distance from the top of an ablation stake to a $1 \mathrm{~m}$ ruler placed on the glacier surface downstream of the stake, i.e. the "straight edge" method. The difference in successive measurements, multiplied by an assumed ice density of $900 \mathrm{~kg} \mathrm{~m}^{-3}$, gave the ice ablation in the period between the two readings, i.e. usually $1 \mathrm{~d}$. The straight edge allowed the determination of an "average" ice level around the stake, and thereby reduced the error caused by the "ablation hollow" at the stake. A constant ice density is not quite correct as the ice surface often has a "weathering crust" of varying depth and density (Müller and Keeler, 1969). This error is correlated to some degree with the prevailing weather type and tends to compensate over periods of many days; it does not significantly affect the monthly and seasonal ablation totals discussed here.

There were actually three stakes within a few metres of each other, so the ablation data are three-stake averages. Despite their close proximity, the stakes seldom registered the same ablation because of measurement errors and differences in micro-topography. The inter-stake differ-

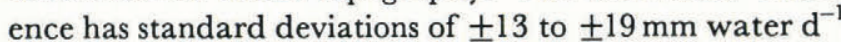
for daily ablation (Braithwaite, 1985b). These errors also tend to compensate over periods of many days.

The monthly ablation for June, July and August at stake 751 (Table 1), together with corresponding winter ablation totals for September-May, refers to net ablation (or ice ablation), as there is apparently little or no snow accumulation on the lower part of the glacier, i.e. up to stake 8 (Fig. 2) which is generally snow-free when the station is re-occupied in May. This means either that the winter snow has blown away before melting starts (no snow melt) or that the snow has melted away before the arrival of the observer (unmeasured snow melt); these possibilities are discussed below. Traces of new snow occur occasionally in cold periods during the summer,

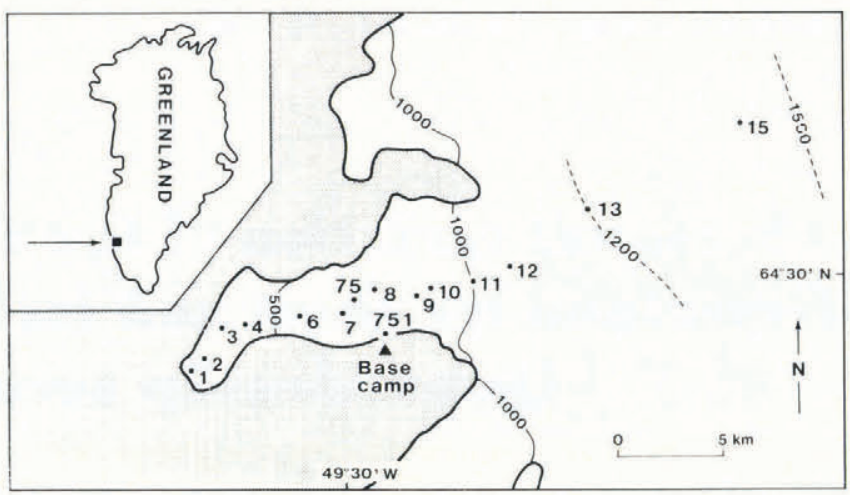

Fig. 2. Sketch map of Qamanârssûp sermia with locations of the base camp and ablation stakes.

with an average frequency of $3 \mathrm{~d}$ per month.

Although there are substantial variations between years, the general pattern is for maximum ice ablation in July, high ablation in June and August, and low ice ablation over the rest of the year. The summer months June-August account for $81 \%$ of the average annual ablation for the 7 years, whereas the total ice ablation for the 9 months from September to May only account for $19 \%$ of the average annual ice ablation.

\section{Air temperature}

Climate recordings, including air temperature, were made concurrently with the glaciological measurements. This involved (1) the summer operation of simple recorders by the Geological Survey of Greenland (GGU) supplemented by hand observations, and (2) the year-round operation of a Danish-built automatic climate station by the Greenland Technical Organization (GTO). The GGU and GTO stations were located about $200 \mathrm{~m}$ apart at base camp and approximately $1 \mathrm{~km}$ from stake 751 on the glacier margin (Fig. 2), which is about $30 \mathrm{~m}$ higher in elevation than the climate stations. After September 1986, the field programme was reduced to twice-yearly measurements of ablation at a few stakes, but the GTO automatic climate station continued to operate for a further 4 years until it was dismantled in the summer of 1990 .

The thermograph records from the GGU station were

Table 1. Ablation at Qamanârssûp sermia ( $m m$ water)

\begin{tabular}{|c|c|c|c|c|c|c|c|c|}
\hline & $1979 / 80$ & $1980 / 81$ & $1981 / 82$ & $1982 / 83$ & $1983 / 84$ & $1984 / 85$ & $1985 / 86$ & Mean \\
\hline Sep.-May & 840 & 920 & 850 & 820 & 450 & 1440 & 730 & 860 \\
\hline Jun. & 910 & 1110 & 1070 & 890 & 1000 & 1460 & 570 & 1000 \\
\hline Jul. & 1330 & 1860 & 1580 & 1460 & 1700 & 1530 & 1700 & 1590 \\
\hline Aug. & 1010 & 800 & 1160 & 570 & 1110 & 1450 & 1460 & 1080 \\
\hline Sep.-Aug. & 4090 & 4690 & 4660 & 3740 & 4260 & 5880 & 4460 & 4540 \\
\hline
\end{tabular}


checked and corrected by twice-daily (morning and evening) manual readings of present temperature as well as maximum and minimum temperatures. The records were generally reliable, but corrections of up to $1^{\circ}$ were occasionally indicated by the hand readings. The automatic climate station was operated entirely unsupervised, but the temperature data for the summer period were found to be highly correlated with the handcollected data, although there is a systematic difference of $+0.63^{\circ}$ (mean value with standard deviation $\pm 0.18^{\circ}$ ) between the two records. The latter is assumed to be a systematic error of the automatic climate station, e.g. caused by faulty adjustment, and the data are corrected accordingly.

The monthly mean temperatures estimated at stake 751 for the 11 years are shown in Table 2. Data for June to August for 1980-86 are extrapolated from the GGU station with a reduction of $0.2^{\circ}$ to account for the $30 \mathrm{~m}$ higher elevation of stake 751 compared with the climate station. Data for September-May in all years, and JuneAugust after 1986, are taken from the GTO station, corrected by $0.63^{\circ}$ in addition to the $0.2^{\circ}$ reduction already mentioned.

The amount of temperature data collected is a tribute to the technical quality of the automatic station, which functioned at low temperatures and in high winds. In particular, complete temperature data are available for 4 out of the 7 years with detailed ablation records (Table 1 ), whereas data for three of the years are incomplete (1979-80 and 1980-81 due to electronic failures, 1984-85 due to physical damage, presumably by high winds).

\section{BACKGROUND AND METHOD}

A study of seasonal ablation variations requires estimates of monthly ice ablation through the entire year. However, for the months September-May, we only have the ablation sum. This lack of monthly winter data is overcome in the present study by using temperature data to interpolate the measured ablation total between the different winter months. In particular, there is a strong relationship between ice ablation and air temperature in the form of the positive degree-day total PDD (Braithwaite and Olesen, 1989a).

$$
a_{\mathrm{i}}=k \cdot \mathrm{PDD},
$$

where $a_{\mathrm{i}}$ is the ice ablation in an $N$-day period, and $k$ is the degree-day factor, which is often treated as a constant although it implicitly depends upon the surface energy balance (Braithwaite and Olesen, 1990c). The positive degree-day total PDD is the sum of positive temperatures in the same $N$-day period:

$$
\mathrm{PDD}=\sum_{t=1}^{n} H_{t} \cdot T_{t},
$$

where $T_{t}$ is the daily mean air temperature on day $t$, and $H_{t}$ is a logical variable such that $H_{t}=1.0$ for $T_{t} \geq 0^{\circ} \mathrm{C}$ and $H_{t}=0.0$ for $T_{t}<0^{\circ} \mathrm{C}$. Strictly speaking, it might be better to define $T_{t}$ in terms of a daily degree-day total, because daily mean temperatures can sometime be negative while temperatures are actually above freezing for part of the day. However, the familiar daily mean air temperature is used here for convenience in using conventional climatological data. According to Equation (1), monthly ablation can be calculated from the degreeday total for the same month.

There is a further problem that some temperature data are missing at Qamanârssûp sermia. In these cases, temperatures are estimated from data at the long-term weather station Nuuk (formerly called Godthåb) on the coast of Greenland (Fig. 1).

Table 2. Monthly mean temperatures at Qamanârssûp sermia $\left({ }^{\circ} \mathrm{C}\right)$

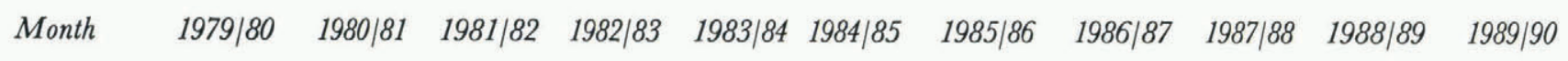

\begin{tabular}{lrrrrrrrrrrr} 
Sep. & -0.9 & -0.5 & 1.7 & -3.1 & -0.7 & $\mathrm{~m}$ & 0.9 & 2.8 & 0.3 & $\mathrm{~m}$ & -2.8 \\
Oct. & -6.9 & -3.8 & -5.8 & -5.3 & -7.2 & $\mathrm{~m}$ & -6.5 & -8.4 & -6.4 & $\mathrm{~m}$ & -7.0 \\
Nov. & -12.9 & -7.5 & -10.3 & -12.9 & -9.1 & $\mathrm{~m}$ & -7.0 & -14.5 & -8.7 & $\mathrm{~m}$ & -6.6 \\
Dec. & -15.0 & -9.6 & -8.7 & -16.0 & -12.0 & $\mathrm{~m}$ & -8.3 & -15.1 & -10.2 & $\mathrm{~m}$ & -9.8 \\
Jan. & -8.9 & $\mathrm{~m}$ & -10.3 & -24.9 & -22.6 & $\mathrm{~m}$ & -10.5 & -11.2 & -14.3 & -18.6 & -16.1 \\
Feb. & $\mathrm{m}$ & $\mathrm{m}$ & -17.6 & -15.7 & -25.3 & $\mathrm{~m}$ & -5.9 & -13.0 & -10.5 & -19.4 & -18.2 \\
Mar. & $\mathrm{m}$ & $\mathrm{m}$ & -14.8 & -16.8 & -12.5 & $\mathrm{~m}$ & -15.7 & -13.1 & -8.4 & -20.6 & -15.0 \\
Apr. & $\mathrm{m}$ & $\mathrm{m}$ & -8.1 & -6.7 & -12.9 & $\mathrm{~m}$ & -6.4 & -10.1 & -7.8 & -8.3 & -11.9 \\
May & $\mathrm{m}$ & -1.6 & -1.8 & -0.8 & -1.6 & $\mathrm{~m}$ & -2.1 & -0.9 & -1.8 & -2.9 & 0.4 \\
Jun. & 4.5 & 5.0 & 4.7 & 3.1 & 4.2 & 5.4 & 2.4 & 6.6 & 1.7 & 3.4 & 4.0 \\
Jul. & 6.4 & 7.3 & 5.8 & 5.0 & 7.3 & 6.2 & 6.8 & 5.3 & 7.1 & 6.3 & $\mathrm{~m}$ \\
Aug. & 5.3 & 3.7 & 4.1 & 1.6 & 4.5 & 6.0 & 5.8 & 6.4 & $\mathrm{~m}$ & 4.2 & $\mathrm{~m}$ \\
\hline
\end{tabular}

$\mathrm{m}=$ missing data. 


\section{RESULTS}

\section{Missing temperature data}

Monthly mean temperatures at Nuuk for 1961-81 are published in "provisional" annual summaries by the Danish Meteorological Institute, Copenhagen. Unpublished data for 1982-90 were kindly provided by the Danish Meteorological Institute.

Monthly mean summer temperatures at Qamanârssûp sermia are roughly the same as those in Nuuk despite the higher elevation, i.e. $790 \mathrm{~m}$ compared with $48 \mathrm{~m}$ a.s.l. Using a vertical lapse rate of about -0.006 to $-0.01^{\circ} \mathrm{m}^{-1}$, equivalent-elevation temperatures at Qamanârssûp sermia are $4.5-7.4^{\circ}$ warmer than at Nuuk in the summer, although winter temperatures at Qamanârssûp sermia are much lower. This reflects the greater continentality of the interior of Godthåbsfjord compared with the coast, first described by Rink (1877). The comparison of temperatures between Qamanârssûp sermia and Nuuk must, therefore, include a seasonal term to take account of this continentality effect.

Brunt (1924) proposed a continentality index which included the seasonal variation of solar radiation. This prompted us to include the monthly extraterrestrial radiation $Q_{0}$ in our analysis, calculated for $64^{\circ} \mathrm{N}$ using the formula in Sellers (1965, p. 232). The temperature difference between Qamanârssûp sermia and Nuuk is plotted against extraterrestrial radiation in Figure 3 for all available temperature data 1979-90 (107 months). The correlation is far from perfect, but the seasonal variation in the temperature differences is clear.

Correlations between monthly mean temperatures at Qamanârssûp sermia $T_{\mathrm{Q}}$ and at Nuuk $T_{\mathrm{N}}$, and extraterrestrial radiation $Q_{0}$ are shown in Table 3 . There is a very high correlation $(r=0.98)$ between temperatures in Qamanârssûp sermia and at Nuuk, but this is partly "forced" by the common annual cycle in both sets of

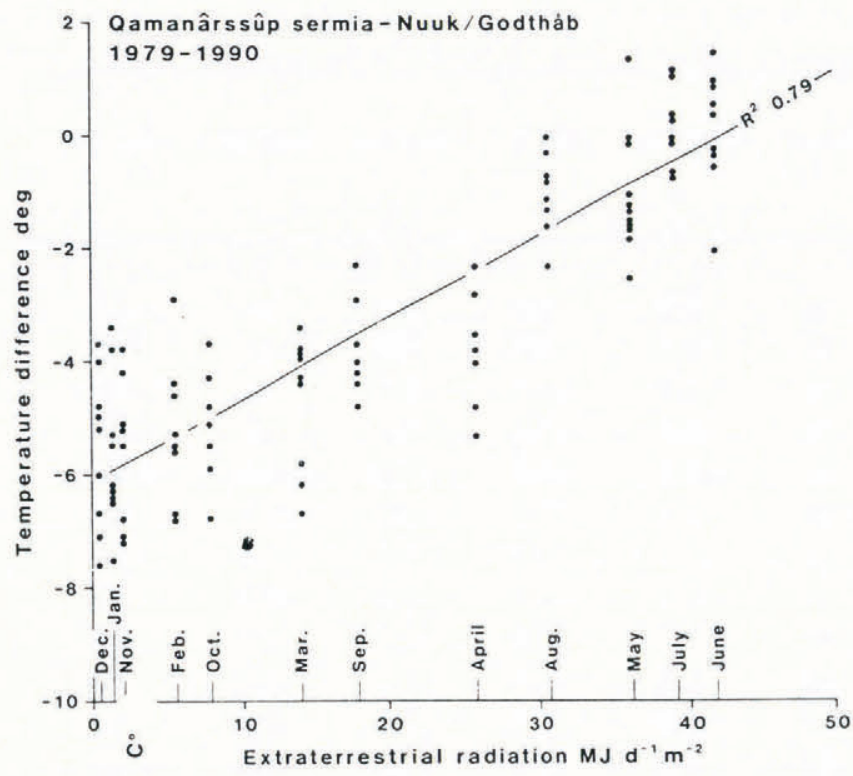

Fig. 3. Temperature difference between Qamanârssûp sermia and Nuuk versus extraterrestrial radiation. Data refer to monthly means.
Table 3. Correlations between monthly temperature at Qamanârssûp sermia $T_{\mathrm{Q}}$, and at $\mathcal{N u u k} T_{\mathrm{N}}$ and extraterrestrial radiation $Q_{0}$ (sample size 107 months)

$\begin{array}{lll}T_{\mathrm{Q}} & T_{\mathrm{N}} \quad Q_{0}\end{array}$

$\begin{array}{llll}T_{\mathrm{Q}} & 1.00 & 0.98 & 0.79 \\ T_{\mathrm{N}} & & 1.00 & 0.69 \\ Q_{0} & & & 1.00\end{array}$

data, as shown, for example, by the fairly strong correlations $r=0.79$ and $r=0.69$ between temperatures at the respective stations and the extraterrestrial radiation. The multiple regression equation for temperatures at Qamanârssûp sermia in terms of temperature in Nuuk and the extraterrestrial radiation is:

$$
T_{\mathrm{Q}}=-5.66+1.06 T_{\mathrm{N}}+0.13 Q_{0} ; \quad R^{2}=0.98,
$$

with a sample size of 107 months. Although the equation accounts for a very large proportion of the temperature variance, as indicated by the high value of $R^{2}$, the temperature variance is also large. The root mean square error of the equation is $\pm 1.2^{\circ}$, which indicates the accuracy with which missing temperatures can be estimated.

\section{Ablation and degree-day totals}

The positive degree-day total was calculated for each month (Table 4) from monthly mean temperature according to the method of Braithwaite (1985a) which uses a probability model instead of the time summation in Equation (2). The corresponding degree-day factor is found by dividing the ablation by the positive degreedays for the same period, i.e. the winter ablation for September-May, monthly ablation for June, July and August, and ablation for the year September-August (Table 5).

Degree-day factors for the summer months JuneAugust are generally similar, with an apparent maximum in July. It is noteworthy that degree-day factors are higher for the winter than for the summer (i.e. an average of 9.43 compared with $7.32-7.96 \mathrm{~mm}$ water $\mathrm{d}^{-1} \mathrm{deg}^{-1}$ ). This seems surprising because the average radiation balance is highly negative during the winter. However, ablation is usually zero during most winter months and the relatively small amount of winter ablation evidently occurs under rare weather conditions. The degree-day factor describes ablation in these cases when it occurs. For example, short periods with Föhn-type weather involve high temperatures and high wind speeds, resulting in high sensible-heat fluxes. This produces relatively high ablation in relation to the temperature, i.e. a high degreeday factor, as already shown for Föhn conditions in the summer (Braithwaite and Olesen, 1990c). Another possibility is that the daily mean temperature in Equation (2) underestimates the daily degree-day total 
Table 4. Monthly degree-day totals at Qamanârssûp sermia (degree-days)

\begin{tabular}{|c|c|c|c|c|c|c|c|c|}
\hline & $1979 / 80$ & $1980 / 81$ & $1981 / 82$ & $1982 / 83$ & $1983 / 84$ & $1984 / 85$ & $1985 / 86$ & Mean \\
\hline Sep. & 35 & 41 & 77 & 15 & 38 & [39] & 62 & 44 \\
\hline Oct. & 2 & 11 & 4 & 5 & 2 & [2] & 3 & 4 \\
\hline Nov. & 0 & 2 & 0 & 0 & 0 & [0] & 2 & 0 \\
\hline Dec. & 0 & 0 & 0 & 0 & 0 & [0] & 1 & 0 \\
\hline Jan. & 0 & [0] & 0 & 0 & 0 & [1] & 0 & 0 \\
\hline Feb. & [0] & [0] & 0 & 0 & 0 & [0] & 3 & 0 \\
\hline Mar. & [0] & [0] & 0 & 0 & 0 & [0] & 0 & 0 \\
\hline Apr. & [1] & [2] & 1 & 2 & 0 & [6] & 3 & 2 \\
\hline May & [56] & 28 & 26 & 38 & 28 & [91] & 23 & 41 \\
\hline Jun. & 143 & 156 & 148 & 108 & 135 & 167 & 92 & 135 \\
\hline Jul. & 201 & 228 & 183 & 161 & 228 & 195 & 213 & 201 \\
\hline Aug. & 169 & 127 & 137 & 78 & 148 & 189 & 183 & 147 \\
\hline Sep.-May & 94 & 84 & 108 & 60 & 68 & 138 & 96 & 93 \\
\hline Jun.-Aug. & 513 & 510 & 468 & 347 & 510 & 551 & 489 & 484 \\
\hline Sep.-Aug. & 607 & 594 & 577 & 407 & 579 & 689 & 585 & 577 \\
\hline
\end{tabular}

[ ] Based on estimated temperature.

for days with temperatures close to the freezing point so that the degree-day factor is correspondingly overestimated (personal communication from G. Wendler).

As a snow surface has a much lower degree-day factor than an ice surface, e.g. summer values of 2.5 and 72. $\mathrm{mm} \mathrm{d}^{-1} \mathrm{deg}^{-1}$, respectively, for Nordbogletscher in south Greenland (Braithwaite and Olesen, 1988), the high winter degree-day factors found here are indirect evidence against the hypothesis mentioned above, of snow melt before the arrival of the observer in mid- or lateMay.

\section{Seasonal ablation variations}

Monthly ablation is calculated for each winter month from monthly degree-day totals (Table 4) and degree-day factors (Table 5). The results (Table 6) can only be approximate, as the real degree-day factors must be different for individual months, but they show the main pattern of ablation which reflects the large variation in degree-day totals.

Average temperatures for September and May are below $0^{\circ}$, so that freezing conditions predominate, although there is still substantial ablation during these months (i.e. about $0.4 \mathrm{~m}$ water on average in both months, which accounts for $17 \%$ of average annual ice ablation for the 7 years studied). By contrast, there is little or no ablation in the months October-April, which only account for about $2 \%$ of average annual ice ablation. There are year-to-year variations in this pattern. For example, slightly above average ablation in May 1983 was offset by low ablation in summer 1983, whilst high ablation in May 1985 was reinforced by high ablation the following summer.

Table 5. Degree-day factors at Qamanârssûp sermia (mm water $\left.d^{-1} \mathrm{deg}^{-1}\right)$

\begin{tabular}{|c|c|c|c|c|c|c|c|c|}
\hline & $1979 / 80$ & $1980 / 81$ & $1981 / 82$ & $1982 / 83$ & $1983 / 84$ & $1984 / 85$ & $1985 / 86$ & Mean \\
\hline Sep.-May & 8.95 & 10.94 & 7.84 & 13.67 & 6.61 & 10.40 & 7.60 & 9.43 \\
\hline Jun. & 6.38 & 7.12 & 7.23 & 8.25 & 7.41 & 8.76 & 6.19 & 7.33 \\
\hline Jul. & 6.62 & 8.16 & 8.62 & 9.07 & 7.46 & 7.85 & 7.98 & 7.96 \\
\hline Aug. & 5.96 & 6.32 & 8.49 & 7.31 & 7.53 & 7.67 & 7.96 & 7.32 \\
\hline Sept.-Aug. & 6.74 & 7.89 & 8.08 & 9.19 & 7.36 & 8.53 & 7.63 & 7.92 \\
\hline
\end{tabular}


Table 6. Monthly ablation at Qamanârssûp sermia (mm water)

\begin{tabular}{|c|c|c|c|c|c|c|c|c|}
\hline & $1979 / 80$ & $1980 / 81$ & $1981 / 82$ & $1982 / 83$ & $1983 / 84$ & $1984 / 85$ & $1985 / 86$ & Mean \\
\hline Sep. & {$[315$} & 444 & 609 & 203 & 251 & 409 & 473 & $386]$ \\
\hline Oct. & {$[19$} & 123 & 28 & 70 & 12 & 21 & 19 & $42]$ \\
\hline Nov. & {$[0$} & 16 & 0 & 0 & 0 & 0 & 14 & 4] \\
\hline Dec. & {$[0$} & 0 & 0 & 0 & 0 & 0 & 5 & 1] \\
\hline Jan. & {$[0$} & 0 & 0 & 0 & 0 & 10 & 0 & 2] \\
\hline Feb. & {$[0$} & 0 & 0 & 0 & 0 & 0 & 23 & 3] \\
\hline Mar. & {$[0$} & 0 & 0 & 0 & 0 & 0 & 0 & 0] \\
\hline Apr. & {$[6$} & 26 & 7 & 30 & 0 & 57 & 19 & 21] \\
\hline May & {$[499$} & 311 & 205 & 518 & 188 & 943 & 176 & $406]$ \\
\hline Jun. & 910 & 1110 & 1070 & 890 & 1000 & 1460 & 570 & 1001 \\
\hline Jul. & 1330 & 1860 & 1580 & 1460 & 1700 & 1530 & 1700 & 1594 \\
\hline Aug. & 1010 & 800 & 1160 & 570 & 1110 & 1450 & 1460 & 1080 \\
\hline Sep.-May & 840 & 920 & 850 & 820 & 450 & 1440 & 730 & 864 \\
\hline Jun.-Aug. & 3250 & 3770 & 3810 & 2920 & 3810 & 4440 & 3730 & 3676 \\
\hline Sep.-Aug. & 4090 & 4690 & 4660 & 3740 & 4260 & 5880 & 4460 & 4540 \\
\hline
\end{tabular}

[ ] Estimated from degree-day model.

\section{GLIMATE GHANGE}

Climate change is simulated by (1) changing the mean monthly temperatures, (2) re-calculating the degree-day totals using the model of Braithwaite (1985b), and (3) recalculating the monthly ablation from the degree-day factors in Table 5. The latter assumption of unchanged degree-day factors under climate change implies that wind speed, radiation, etc. are constant with respect to temperature change, which need not be true, but there is no plausible alternative at present.

\section{Effects of temperature}

The monthly ablation distribution for present climate, as well as for higher temperature, is plotted in Figure 4. Higher temperature causes higher ablation for the present ablation season (with average temperature over $0^{\circ}$ ) of June-August, but there is a proportionally greater increase of ablation in May and September, which quickly join the ablation season for a temperature increase of only $+1^{\circ}$. However, the other months, October-April, are presently so cold that even a $+5^{\circ}$ temperature increase is not enough to bring them into the ablation season. Naturally, ablation in these months increases, especially in October and April, but days with ablation will still be comparatively rare.

The increase of ice ablation with temperature is plotted in Figure 5, assuming that all months have the same temperature change. The increase in annual ice ablation is about $1 \mathrm{~m}$ water $\mathrm{a}^{-1}$ per degree temperature rise; ablation will more than double with $\mathrm{a}+5^{\circ}$ temperature change.

According to the Intergovernment Panel on Climate
Change (WMO/UNEP, 1990), the global annual mean temperature may rise by about $0.3^{\circ}$ per decade. Making the somewhat dubious assumption that this applies to Greenland, ablation at the margin of the ice sheet will increase by about $0.3 \mathrm{~m}$ water $\mathrm{a}^{-1}$ per decade. As there will still be little or no ablation in the coldest months, this ablation increase will involve mainly a larger amplitude for seasonal variations in ablation. However, there are some indications from global climatic models (Mitchell and others, 1990) that greenhouse warming may involve much smaller increases for summer temperatures than for winter temperatures. The result, in this case, will be a smaller increase in total ablation than shown in Figure 5. For example, annual ablation will hardly increase at all in the extreme case of higher temperatures only in the coldest months.

Discussion exists in the literature as to whether the main effect of temperature change is to increase the amount of ablation during the ablation season or to increase the length of the ablation season (Hoinkes, 1955; Ambach, 1972). The present results agree with Ahlmann (1953, p. 14) that "High spring and autumn temperatures prolong the ablation period, high summer temperatures intensify it".

\section{Effects of accumulation}

It is not clear whether or not the patterns in Figures 4 and 5 represent conditions over a larger area. This is a legitimate question, as the present data come from the margin of the ice sheet, which has relatively high temperatures and little or no snow accumulation compared with the greater part of the ablation area. In particular, the present results could be modified by the 


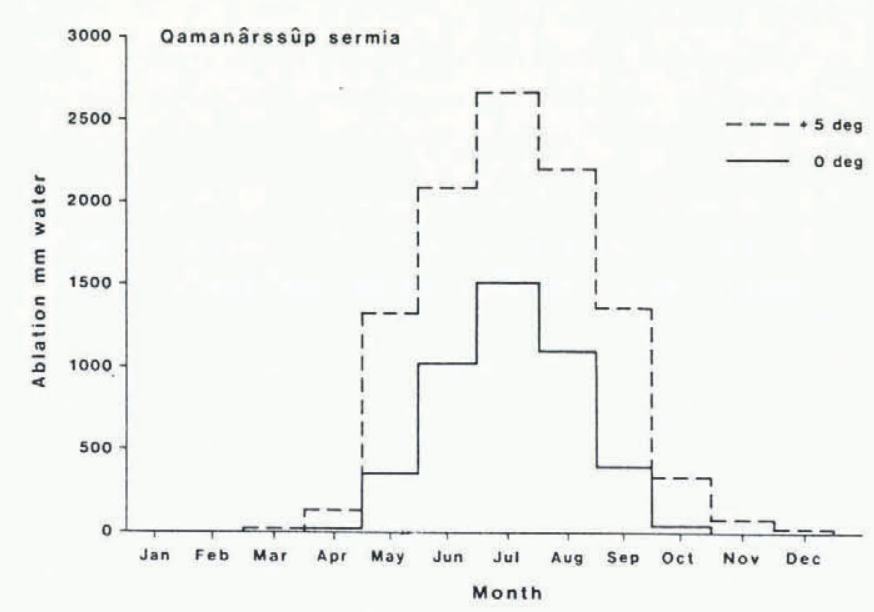

Fig. 4. Simulated monthly distribution of ice ablation at the margin of Qamanârssûp sermia for different climates.

effects of snow accumulation. For example, Braithwaite and Olesen (1988) proposed a modified degree-day relationship for the ice ablation $a_{\mathrm{i}}$, which occurs after the ablation of a snow cover:

$$
a_{\mathrm{i}}=k_{\mathrm{i}}\left(\mathrm{PDD}-c / k_{\mathrm{s}}\right),
$$

where $c$ is the water equivalent of the snow accumulation (equal to the snow ablation in this case) and $k_{\mathrm{i}}$ and $k_{\mathrm{s}}$ are the degree-day factors for ice and snow, respectively. According to Equation (4), ice ablation depends upon the degree-day factors for ice and snow, as well as the accumulation. The hypothetical reduction in ice ablation caused by increasing accumulation is plotted in Figure 6 for different values of the degree-day factor for snow ablation, assuming PDD $=577$ degree-day from Table 4 .

Under the present climate, it is most likely that any winter snow at the margin of Qamanârssûp sermia would be blown away ayain, and therefore not participate in the ablation process. A similar situation exists on the lower part of the Greenland ice sheet near Ilulissat (Thomsen and others, 1988). In the future, warmer winter temperatures at these sites may result in an increase in the amount of snowfall by increasing precipitation and

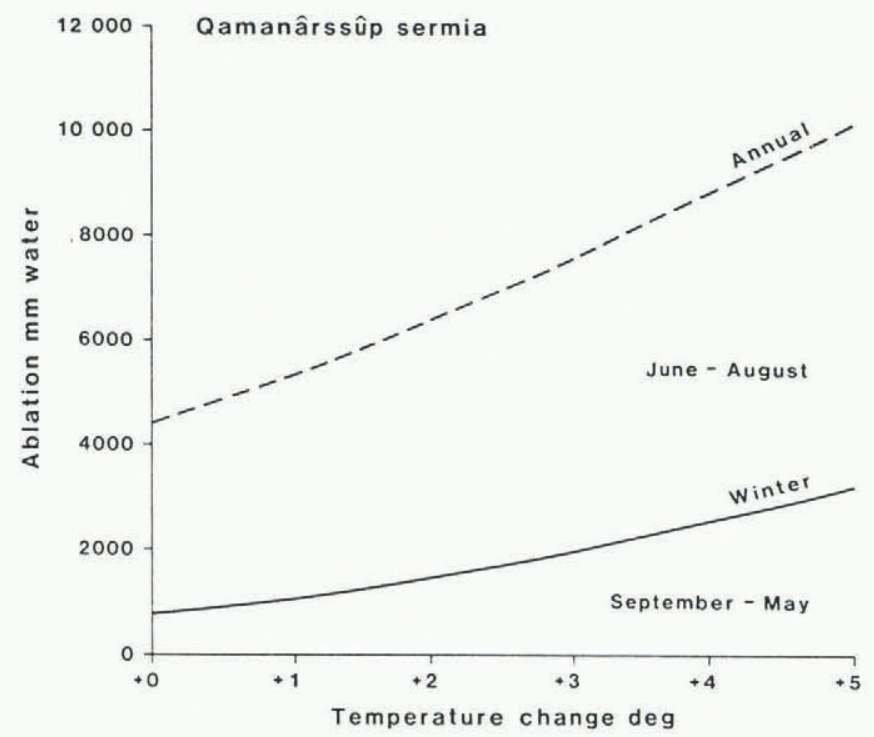

Fig. 5. Simulated ice ablation at the margin of Qamanârssûp sermia as a function of temperature change. wetting the snow so that it cannot be blown away. The snow would therefore be forced to stay on the ground to suffer ablation, i.e. to use ablation energy and thereby reduce the energy available for ice ablation. The opposite could occur at a site where there is already substantial accumulation and ablation of snow under present climate conditions, e.g. Nordbogletscher in south Greenland (Braithwaite and Olesen, 1988). In this case, higher temperatures in the winter may change snowfall into rainfall to reduce snow accumulation and thereby increase the energy available for ice ablation.

\section{MONITORING}

Methods must be developed to monitor changes of the Greenland ice sheet caused by increased melting due to climate change. Satellite-radar altimetry is a powerful potential method whereby changes in surface elevation of the ice sheet can be measured directly.

The elevation change of the ice surface in the ablation zone is determined by the difference between emergence velocity of ice flow and the local ablation rate. Emergence velocity is probably rather constant over a few years, whereas seasonal variations in ablation will cause fluctuations in surface elevation, e.g. a slow thickening during winter, followed by a rapid thinning during the shorter summer, which will be further emphasized by variations in seasonal snow cover. The monitoring of surface elevations must therefore be designed to detect any long-term changes against this background of large seasonal changes. For example, satellite-radar altimetry shows a fluctuation of $\pm 1.6 \mathrm{~m}$ ice in ablation area elevation between spring 1985 and summer 1986 compared with a thinning trend of only $-0.5 \mathrm{~m}$ ice (Lingle and others, 1990).

The present study was partly motivated by the suspicion that the recent thickening of the Greenland ice sheet, reported by Zwally and others (1989), might be an artefact of seasonal ablation variations. For example, the three periods of coverage by satellite altimetry all

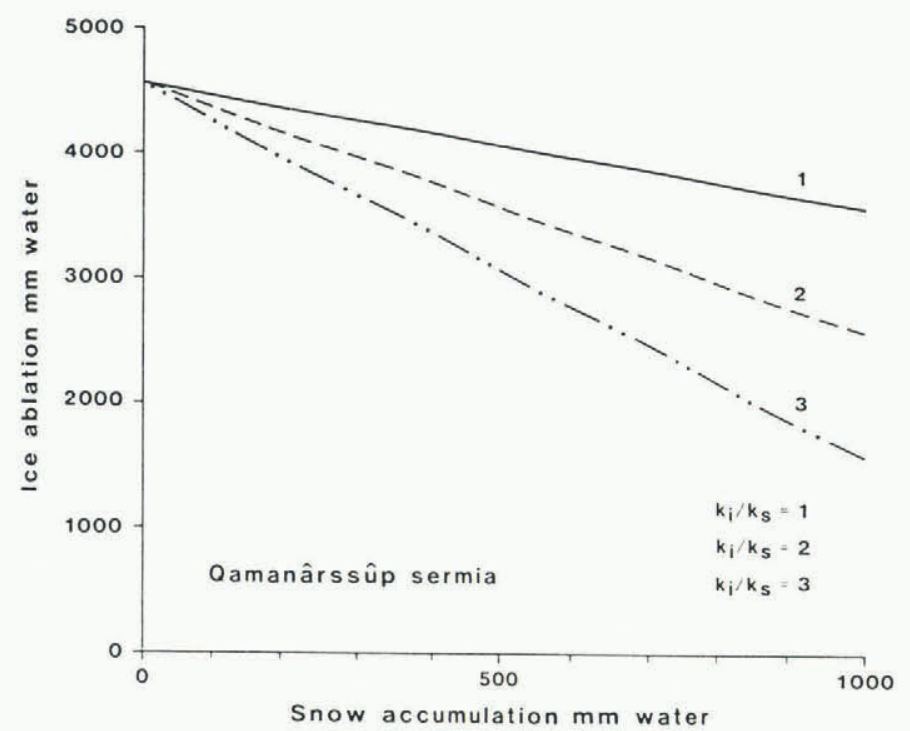

Fig. 6. Simulated ice ablation at the margin of Qamanârssûp sermia as a function of snow accumulation. 
include incomplete annual cycles: April 1975-June 1978, July 1978-October 1985 and April 1985-September 1986. However, thickness changes measured from April (the end of winter) to some time in the summer should, if anything, be biased towards thinning rather than thickening. The thickening detected by satellite-radar altimetry cannot therefore be an artefact of seasonal effects, and may even underestimate the actual thickening, all things being equal.

\section{ACKNOWLEDGEMENTS}

This paper is published by permission of the Geological Survey of Greenland (GGU) and its preparation was supported by the European Community through contract EPOC-CT90-0015. We thank the many assistants who collected data at Qamanârssûp sermia during seven summers, especially those who came at least twice: J. Andsbjerg, C. Bøggild, B. Christiansen, I. Eiríksdóttir, and A. Engraf (Copenhagen University), and J.-O. Andreasen and $\mathrm{O}$. Bendixen (Aarhus University). The automatic climate station was operated by the Greenland Technical Organization (GTO) and data were processed by T. Thomsen, C. Kern-Hansen and O. Smith of that organization. Unpublished temperaturedata for Nuuk 1982-90 were kindly provided by P. Frich, Database Section, Danish Meteorological Institute (DMI), Copenhagen.

\section{REFERENCES}

Ahlmann, H.W. 1953. Glacier variations and climatic fluctuations. New York, American Geographical Society.

Ambach, W. 1972. Zur Schätzung der Eis-Nettoablation im Randgebiet des grönländischen Inlandeises. Polarforschung, 42(1), 18-23.

Braithwaite, R.J. 1985a. Glaciological investigations at Qamanârssûp sermia, West Greenland, 1983-1984. Gronlands Geologiske Undersegelse. Gletscher-Hydrologiske Meddelelser 85/3.

Braithwaite, R.J. 1985b. Calculation of degree-days for glacier-climate research. Z. Gletscherkd. Glazialgeol., 20, 1984, 1-8.

Braithwaite, R. J. and O. B. Olesen. 1985. Ice ablation in West Greenland in relation to air temperature and global radiation. Z. Gletscherkd. Glazialgeol., 20, 1984, 155-168.

Braithwaite, R.J. and O.B. Olesen. 1988. Winter accumulation reduces summer ablation on Nordbogletscher, south Greenland. Z. Gletscherkd. Glazialgeol., 24(1), 21-30.

Braithwaite, R.J. and O. B. Olesen. 1989a. Calculation of glacier ablation from air temperature, West Greenland. In Oerlemans, J., ed. Glacier fluctuations and climatic change. Dordrecht, Kluwer Academic Publishers, 219233,
Braithwaite, R.J. and O. B. Olesen. 1989b. Detection of climate signal by inter-stake correlations of annual ablation data, Qamanârssûp sermia, West Greenland. J. Glaciol. 35(120), 253-259.

Braithwaite, R.J. and O. B. Olesen. 1990a. Increased ablation at the margin of the Greenland ice sheet under a greenhouse-effect climate. Ann. Glaciol., 14, 2022.

Braithwaite, R.J. and O.B. Olsesen. 1990b. A simple energy-balance model to calculate ice ablation at the margin of the Greenland ice sheet. F. Glaciol., 36(123), 222-228.

Braithwaite, R.J. and O.B. Olesen. 1990c. Response of the energy balance on the margin of the Greenland ice sheet to temperature changes. F. Glaciol., 36(123), 217221.

Brunt, D. 1924. Climatic continentality and oceanity. Geogr. F., 64(1), 43-56.

Hoinkes, H. 1955. Measurements of ablation and heat balance on alpine glaciers. F. Glaciol., 2(17), 497-501.

Lingle, C. S., A.C. Brenner and H.J. Zwally. 1990. Satellite altimetry, semivariograms, and seasonal elevation changes in the ablation zone of West Greenland. Ann. Glaciol., 14, 158-163.

Mitchell, J.F.B., S. Manabe, V. Meleshko and T. Tokioka. 1990. Equilibrium climatic change - and its implications for the future. In Houghton, J. T., G.J. Jenkins and J.J. Ephraums, eds. Climate change - the IPCC scientific assessment. Cambridge, Cambridge University Press, 131-164.

Müller, F. and C. M. Keeler. 1969. Errors in short-term ablation measurements on melting ice surfaces. 7 . Glaciol., 8(52), 91-105.

Olesen, O. B. and R.J. Braithwaite. 1989. Field stations for glacier-climate research, West Greenland. In Oerlemans, J., ed. Glacier fluctuations and climatic change. Dordrecht, Kluwer Academic Publishers, 207-218.

Rink, H. 1877. Danish Greenland - its people and its products. London, Henry S. King and Co.

Sellers, W.D. 1965. Physical climatology. Chicago, University of Chicago Press.

Thomsen, H.H., L. Thorning and R.J. Braithwaite. 1988. Glacier-hydrological conditions on the inland ice north-east of Jakobshavn/Ilulissat, West Greenland. Grenlands Geologiske Undersegelse. Rapport 138.

Warrick, R. and J. Oerlemans. 1990. Sea level rise. In Houghton, J. T., G. J. Jenkins and J.J. Ephraums, eds. Climate change - the IPCC scientific assessment. Cambridge, Cambridge University Press, 257-281.

WMO-UNEP. 1990. Scientific assessment of climate change. Geneva, World Meteorological Organization and United Nations Environment Programme.

Zwally, H.J., A. C. Brenner, J.A. Major, R.A. Bindschadler and J. G. Marsh. 1989. Growth of Greenland ice sheet: measurement. Science, 246(4937), 1587-1589.

The accuracy of references in the text and in this list is the responsibility of the authors, to whom queries should be addressed. 